\title{
Seasonal fluctuations of the sponge-dwelling gnathiid isopod Elaphognathia aff. cornigera
}

Yuzo Ota, Katsuhiko Tanaka and Euichi Hirose

\begin{abstract}
While records of seasonal abundance patterns are available for gnathiids (Crustacea, Isopoda, Gnathiidae) in temperate zones and cold water populations, none exist for tropical and subtropical populations. We found the gnathiid isopod Elaphognathia aff. cornigera inhabiting sponges on a subtropical tidal flat in the Haneji Island Sea, Ryukyu Archipelago, southwestern Japan. To examine seasonal abundance patterns of this species, we conducted monthly sampling from December 2004 to November 2006 of the demosponge Haliclona sp. in which the gnathiids dwelled. All of the adult males, adult females in various reproductive phases, and larvae of Elaphognathia aff. cornigera were found throughout most of the year, suggesting that the species reproduces year-round. However, gnathiid density showed a remarkable seasonal pattern, with the maximum abundance occurring in spring and the minimum abundance in summer. These results were quite different from temperate species, in which female development and reproduction are restricted to warmer months and the highest densities are often recorded in the summer. Warm subtropical winters would likely not disturb gnathiid growth and reproduction, but extreme environmental conditions, including summer high water temperatures and typhoons, may affect gnathiid density.
\end{abstract}

\author{
Introduction \\ Gnathiids (Crustacea, Isopoda,
} Gnathiidae) have a biphasic life cycle with a parasitic larval phase and a nonfeeding adult phase (Hesse, 1864; Monod, 1926). Larval growth proceeds via several alternating periods of ectoparasitic feeding on host fish, followed by molting in the benthic habitat before individuals reach maturity. Finally, larval gnathiids metamorphose into nonfeeding adults with extremely different morphologies (Mouchet, 1928; Stoll, 1962; Wägele, 1988; Klitgaard, 1991; Tanaka \& Aoki, 1998).

To date, seasonal abundance patterns have been studied for only five gnathiid species from temperate zones and cold water: Paragnathia formica in Europe (Stoll, 1962), Caecognathia robusta and Caecognathia abyssorum in the Northeast Atlantic deep sea (Klitgaard, 1991, 1997), and Elaphognathia cornigera and Elaphognathia discolor in Japan (Tanaka, 2003; Tanaka \& Nishi, 2008). However, no seasonal abundance pattern studies have been conducted in shallow waters of subtropical or tropical zones. In recent years, gnathiids have been commonly recorded and studied as ectoparasites of elasmobranchs (McKiernan et al., 2005) and teleosts (Cheney \& Côté, 2003; Jones et al., 2007) of coral reefs. Furthermore, as ectoparasites, gnathiids participate in cleaning interactions among tropical fishes (Grutter, 1995, 1999a, 1999b, 2003; Arnal \& Côté, 2000; Grutter et al., 2000; Sikkel et al., 2006). Thus, obtaining information regarding seasonal abundance patterns from sub- 

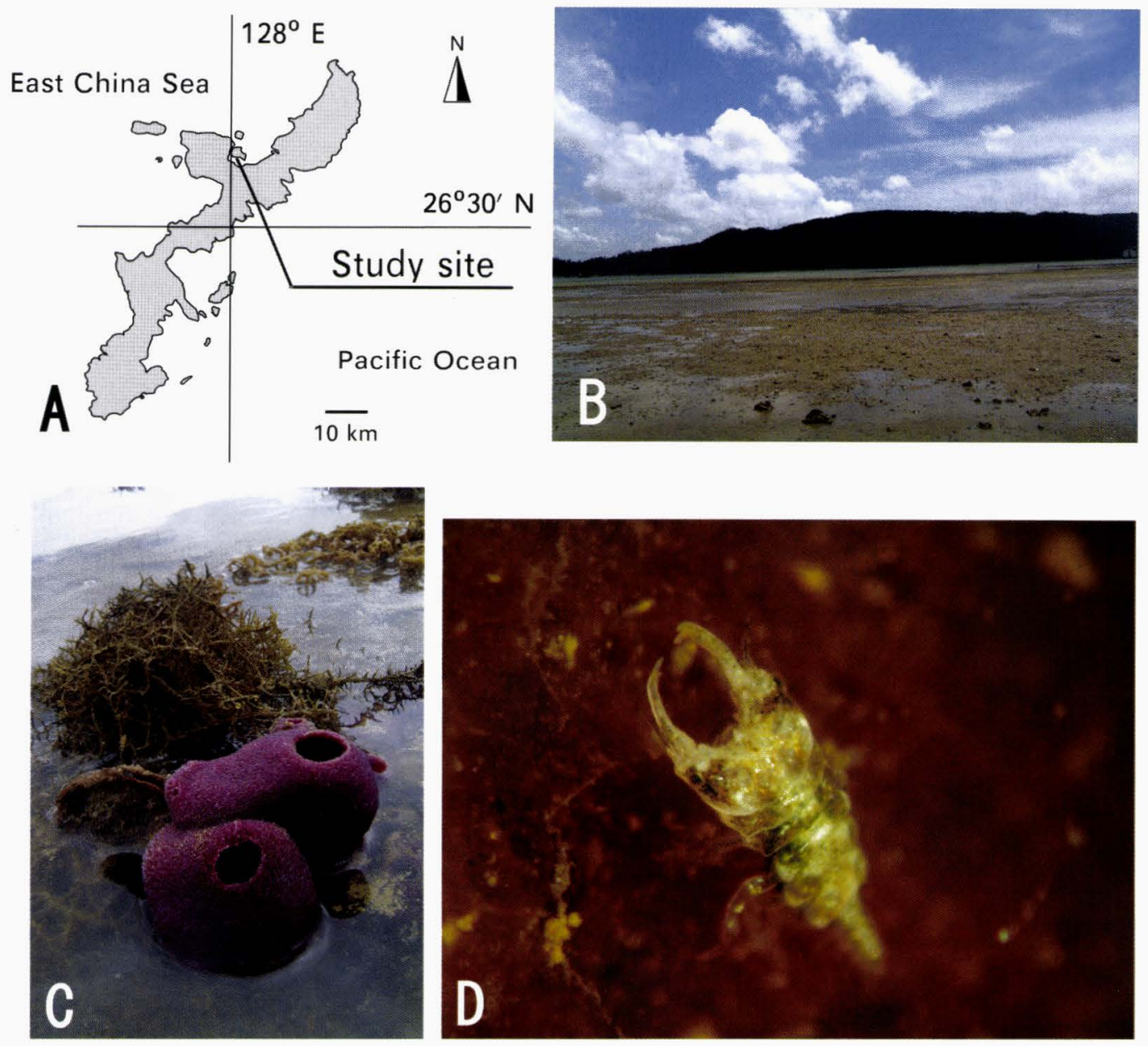

Fig. 1. Study site. A, Map of Okinawa-jima Island showing the study site; B, The tidal flat in the vicinity of Yagaji-jima Island; C, The sponge Haliclona sp. in which Elaphognathia aff. cornigera dwells. The height of Haliclona sp. (ca. $6 \times 4 \mathrm{~cm}$ ); D, Elaphognathia aff. cornigera in the sponge Haliclona sp. Total length of this specimen was about $2.5 \mathrm{~mm}$.

tropical and tropical zones would be of great benefit to understand gnathiid biology, hostparasite and cleaning interactions.

We found a gnathiid species inhabiting sponges on a subtropical tidal flat in the Haneji Island Sea, Yagaji-jima Island, Ryukyu Archipelago, southwestern Japan $\left(26^{\circ} 28^{\prime} \mathrm{N}, 128^{\circ} 0^{\prime} \mathrm{E}\right)$. The gnathiid species is morphologically similar to Elaphognathia cornigera but a few differences exist between the two species. Thus, the present species is temporarily called Elaphognathia aff. cornigera. Elaphognathia cornigera was originally described from Amakusa, Kyushu, southwestern Japan $\left(32^{\circ} 33^{\prime} \mathrm{N}, 130^{\circ} 6^{\prime} \mathrm{E}\right)$ (Nunomura, 1992) and its life cycle (Tanaka \& Aoki, 1998) and population dynamics (Tanaka, 2003) were investigated in temperate waters (Izu Peninsula, southern Japan: $\left.34^{\circ} 40^{\prime} \mathrm{N}, 138^{\circ} 57^{\prime} \mathrm{E}\right)$. In this paper, a seasonal abundance pattern in a subtropical population of Elaphognathia aff. cornigera is discussed based on the results of monthly sampling over two years to better understand 

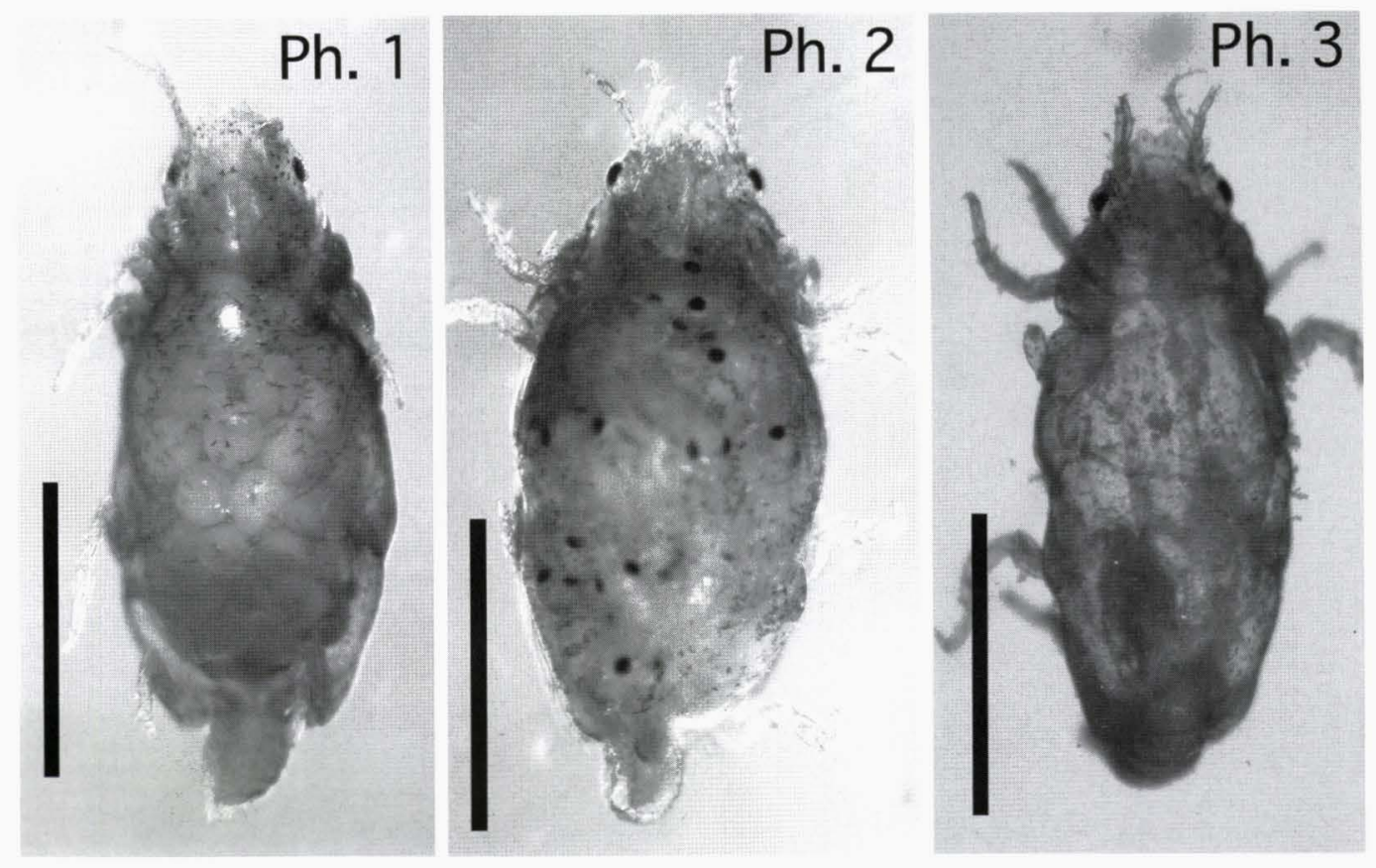

Fig. 2. Ventral view of adult females of Elaphognathia aff. cornigera. Adult females were classified into three reproductive phases ( $\mathrm{Ph} .1$, embryos or eggs in the adult female; $\mathrm{Ph} .2$, embryos having prominent eyes in the breeding pouch; Ph. 3, an empty breeding pouch after larvae were released larvae). Scale bar $=1 \mathrm{~mm}$.

the ecology of gnathiid isopods in the subtropics.

\section{Materials and Methods}

A tidal flat in the vicinity of Yagaji-jima Island $\left(26^{\circ} 28^{\prime} \mathrm{N}, 128^{\circ} 0^{\prime} \mathrm{E}\right)$ was chosen as the collection site for materials (Fig. 1). The tidal flat is primarily composed of muddy sand littered with rocks. Several sponge species grow on the rocks at depths up to 50 $\mathrm{cm}$ during the lowest water levels of the spring tide. Surface seawater temperature was inferred from coastal observations at Sesoko Station, Tropical Biosphere Research Center, University of the Ryukyus $\left(26^{\circ} 38^{\prime} \mathrm{N}, 127^{\circ} 51^{\prime} \mathrm{E}\right)$.

Elaphognathia aff. cornigera has been found from rocks and several sponge species. Among the sponge habitats of the present gnathiid, a reddish purple sponge, Haliclona sp., is conspicuous at the collec- tion site. Haliclona sp. is distributed in infralittoral zone $(0-50 \mathrm{~cm}$ depth below the water level at the spring low tide). The softness of the sponge also makes it suitable for dissection. Therefore, we collected Haliclona sp. monthly from December 2004 to November 2006 at the point of the lowest water level of the spring tide. During each sampling period, 5-12 sponge colonies were collected by hand, and each colony was put in a plastic bottle (500-1000 ml) filled with seawater. After the samples were taken back to the laboratory, each colony was dissected into smaller pieces with forceps to collect infaunal gnathiids. Latex gloves were worn during the dissection because the sponges are venomous. Dissected sponges and gnathiids were fixed in $70 \%$ ethanol. The dissected sponges were dried at $80^{\circ} \mathrm{C}$ for 48 $\mathrm{h}$ in a forced convection oven (FV-630, Advantec) and weighed with an electromagnetic weight-measuring scale (HF-400, A\&D 
Company).

Under a binocular stereomicroscope (SZX12, Olympus), the gnathiids from each sponge colony were classified as larvae, adult males, or adult females on the basis of morphological characteristics, and the adult females were further classified into three reproductive phases (phase 1 , females with eggs or early-stage embryos lacking prominent eyes; phase 2, females with embryos having prominent eyes; phase 3 , females that had released larvae from their ventral brood pouch) (Fig. 2). None of the adult females were found prior to oviposition.

Body lengths of adult males, adult females, and larvae were measured with an ocular micrometer. Larvae and adult females often rolled up during fixation, and thus body length was defined as the distance from the head to the tip of pleotelson without the mandibles for adult males, from the head to the tip of pereonite 6 for adult females, and from the head, without mandibles, to pereonite 6 for pre-feeding and post-feeding larvae. Deformed gnathiids, such as metamorphosing individuals, were not measured because their pereonites were deformed.

Spearman's rank correlation coefficient was used to assess the relationship between the numbers of Elaphognathia aff. cornigera and dry sponge colony weight (= size). Furthermore, to examine gnathiid distribution patterns, Morisita's Index $\mathrm{I}_{\delta}$, a measure of aggregation (Morisita, 1959), was calculated using the number of gnathiids in each sponge from each sampling, and the randomness of the distribution was tested by comparing the variance-mean ratio of the number of gnathiids in each sponge to F-values.

\section{Results}

The gnathiid species in this study

The gnathiids found in Haliclona sp. individuals were morphologically similar to Elaphognathia cornigera (Nunomura, 1992) as for whole proportions, cephalosomes, and mouthparts. This species was originally found in the sponge Haliclona permollis and later rediscovered from the sponge Halichondria okadai (Nunomura, 1992; Tanaka \& Aoki, 2000). However, a few differences exist between the present species and $E$. cornigera. The present species lives in sponges found on a muddy tidal flat, whereas $E$. cornigera inhabits sponges on rocky bottoms. We preliminary compared detailed morphologies between the present species and E. cornigera collected in Shimoda (Izu Peninsula, Japan). In the present species, the adult male had nine plumose setae on pylopod, the adult female had 22 plumose setae on maxilliped, and the larva had 16 setae on lateral margin of pleotelson. In $E$. cornigera, the adult male had six plumose setae on pylopod, the adult female had 20 plumose setae on maxilliped, and the larva had 18 setae on lateral margin of pleotelson. Furthermore, in the present species, larval gnathopods had several notches, but such notches were absent in E. cornigera. However, we have also observed strong variations in the morphologies of the cephalosome and appendages within populations of the present species. Detailed examination will be necessary to clarify the taxonomic status of the present gnathiid and its relationship with $E$. cornigera. Therefore, the present species is called Elaphognathia aff. cornigera in this paper.

\section{Distribution pattern of gnathiids among sponges}

Haliclona sp. has always been found at the study site, and we examined 168 colonies in total. However, we could not obtain weight data for each sponge colony in June 2005 and in February and March 2006 because of technical errors. In July 2006, no sponges were collected because of stormy weather. During sampling in December 2004, eight sponge colonies were collected and deposited together in a bucket. The gnathiids in the sponges mixed within the bucket before sorting, and thus data from that month were not used in examining the 
Table 1. The results of statistical analyses of the relationship between the sponge Haliclona sp. and Elaphognathia aff. cornigera and the number of gnathiids in each month. Morisita's index is also shown in the left column.

\begin{tabular}{|c|c|c|c|c|c|c|c|}
\hline \multirow[b]{2}{*}{ Year } & \multirow[b]{2}{*}{ Month } & \multirow{2}{*}{$\begin{array}{l}\text { Morisita's } \\
\text { Index I } \delta\end{array}$} & \multicolumn{2}{|c|}{$\begin{array}{c}\text { Spearman's rank correlation } \\
\text { coefficient }\end{array}$} & \multirow{2}{*}{$\begin{array}{l}\text { Total N. of } \\
\text { sponge }\end{array}$} & \multirow{2}{*}{$\begin{array}{c}\% \text { of sponge } \\
\text { inhabited by } \\
\text { gnathiids }\end{array}$} & \multirow{2}{*}{$\begin{array}{c}\text { Total N. } \\
\text { of } \\
\text { gnathiid }\end{array}$} \\
\hline & & & rs & $\mathrm{P} *$ & & & \\
\hline 2004 & Dec & - & - & - & 8 & No data & 71 \\
\hline \multirow[t]{12}{*}{2005} & Jan & 5.54 & 0.2 & 0.35 & 5 & 80 & 77 \\
\hline & Feb & 1.4 & -0.3 & 0.8 & 5 & 100 & 56 \\
\hline & Mar & 1.76 & 0.7 & 0.25 & 5 & 100 & 141 \\
\hline & Apr & 1.29 & 0.4 & 0.07 & 5 & 100 & 128 \\
\hline & May & 2.17 & -0.38 & 0.82 & 5 & 60 & 80 \\
\hline & Jun $^{\star *}$ & 2.6 & - & - & 5 & 100 & 55 \\
\hline & Jul & 2.55 & 0 & 0.56 & 5 & 80 & 39 \\
\hline & Aug & 1.78 & -0.81 & 0.95 & 6 & 83 & 80 \\
\hline & Sep & 3.61 & 0.75 & 0.03 & 7 & 43 & 27 \\
\hline & Oct & 3.09 & 0.71 & 0.08 & 6 & 33 & 22 \\
\hline & Nov & 3.58 & 0.6 & 0.02 & 9 & 44 & 39 \\
\hline & Dec & 4.48 & -0.05 & 0.6 & 11 & 55 & 80 \\
\hline \multirow[t]{12}{*}{2006} & Jan & 2.82 & 0.1 & 0.63 & 10 & 50 & 100 \\
\hline & $\mathrm{Feb}^{\star \star}$ & 2.12 & - & - & 9 & 77 & 116 \\
\hline & $\operatorname{Mar}^{\star *}$ & 2.57 & - & - & 8 & 75 & 199 \\
\hline & Apr & 1.79 & 0.21 & 0.46 & 8 & 88 & 174 \\
\hline & May & 7.03 & 0.58 & 0.44 & 12 & 58 & 96 \\
\hline & Jun & 3.91 & 0.21 & 0.56 & 8 & 38 & 10 \\
\hline & Jul & - & - & - & No data & No data & No data \\
\hline & Aug & - & - & - & 8 & 0 & 0 \\
\hline & Sep & 4.31 & -0.43 & 0.82 & 6 & 33 & 13 \\
\hline & Oct & 3.15 & 0.27 & 0.45 & 8 & 38 & 22 \\
\hline & Nov & 2.86 & -0.14 & 0.78 & 9 & 56 & 31 \\
\hline & Total & & & & $168(160)^{\star * *}$ & & 1656 \\
\hline
\end{tabular}

* Significant correlation $(\mathrm{P}<0.05)$ in bold.

** Spearman's test could not be applied, because weight data of each sponge colony were not available.

*** Total number of sponge excluding the data in Dec. 2004 is in parenthesis.

relationship between the number of gnathiids and sponge dry weight.

Elaphognathia aff. cornigera was found in Haliclona sp. during every sampling period except August 2006. Gnathiids were present in 96 of 160 sponge colonies collected from January 2005 to November 2006 (Table 1), excluding specimens from December 2004, and the total number of gnathiids found during the study was 1656 , including specimens from December 2004. One adult male was often found with one female and one premature larva in sponge oscula.

Correlation analysis found no statistically significant relationship between the number of gnathiids and sponge dry weight during most months (Table 1). Morisita's indices were larger than 1 in every month (Table 1 ), suggesting that the present gnathiid species tends to aggregate in a particular sponge 
colony. Furthermore, the variance-mean ratio significantly supports the aggregate distribution in every month $(\mathrm{P}<0.05)$.

\section{Seasonal fluctuations}

Adult males, adult females, and post-feeding larvae of Elaphognathia aff. cornigera were found in Haliclona sp. throughout the year at the study site (Fig. 3A-C) and prefeeding larvae were found from January to May 2006 (Fig. 4C). The proportion of sponges that contained gnathiids tended to increase from winter to spring and decrease in the summer (Table 1).

Because the number of gnathiids was not related to sponge dry weight, the relationship was not used as an index of gnathiid abundance. Instead, the number of gnathiids per sponge colony was applied to assess seasonal changes in population abundance (Fig. $3 \mathrm{~A}-\mathrm{C})$. The abundance of gnathiids was low at the beginning of the investigation (December 2004). Then, the abundances of both larval and adult gnathiids increased after January/February 2005 (Fig. 3A-C). The abundance of gnathiids tended to be low in a warm period and high in a cold period (Fig. 3). Larval abundance peaked in March 2005 (Fig. 3C) and the abundances of both adult males and females increased until April 2005 (Fig. 3A, B). The numbers of both larvae and adults then declined. Although a small peak was observed in August 2005, gnathiids were relatively scarce until November 2005. The seasonal population changes observed in the second year were comparable to the results from the first year.

Male gnathiids outnumbered females in most months (Fig. 3A, B). The male ratio (no. of males / no. of both adults x 100) ranged from 46.5 to $89.8 \%$, increasing from February to March, decreasing during June and July, increasing again around September and October, and diminishing by January (Fig. 3A). Three female reproductive phases were observed almost yearround (Fig. 3B).

Body lengths were not measured for 109 gnathiids because of deformations. Adult males had body sizes (from the head to the tip of the pleotelson without the mandibles) ranging from 1.27 to $2.67 \mathrm{~mm}$ (mean $\pm \mathrm{SD}$, $2.03 \pm 0.22 ; \mathrm{N}=665$ ) and adult females (from the head to the tip of pereonite 6 ) were between 1.25 and $2.31 \mathrm{~mm}$ (mean $\pm \mathrm{SD}, 1.77$ $\pm 0.14 ; \mathrm{N}=405)$. Monthly average body lengths for both sexes tended to increase from fall to winter and decrease from spring to early summer (Fig. 4A, B).

Body size for larvae (from the head without the mandible to pereonite 6 ) ranged from 0.36 to $1.60 \mathrm{~mm}(\mathrm{~N}=477)$. Average body sizes were not shown for larvae because the samples likely included several developmental stages. For example, two size-groups are separated by a broken line in Fig. 4C. Among the larvae measured, 34 individuals were pre-feeding larvae (shown as gray ellipses in Fig. 4C) while the others were post-feeding larvae. Pre-feeding larvae were found from January to May 2006 but not observed in other months. They were small in size $(<1 \mathrm{~mm})$, except for one individual found in March 2006, and were distributed below the broken line in Fig. 4C. However, most of the larger larvae were post-feeding and as large as adults.

\section{Discussion}

The use of Haliclona sp. by Elaphognathia aff. cornigera

Gnathiid species are generally found in, for example, sponges, rocks and dead coral crevices, tubes of terrebellid polychaetes, and mud burrows (Tanaka, 2007), but habitat use has been discussed for only a few gnathiids. In the Antarctic species Caecognathia calva, premature larvae and adults mainly dwell in hexactinellid sponges, but young larval stages are less frequent there and some adults and young larvae also occur in sediments (Wägele, 1988). Elaphognathia cornigera in Izu Peninsula, southern Japan, dwell in some sponge species (Nunomura, 1992; Tanaka \& Aoki, 1998). In this species, individuals of all life stages were found abundantly in the sponge 


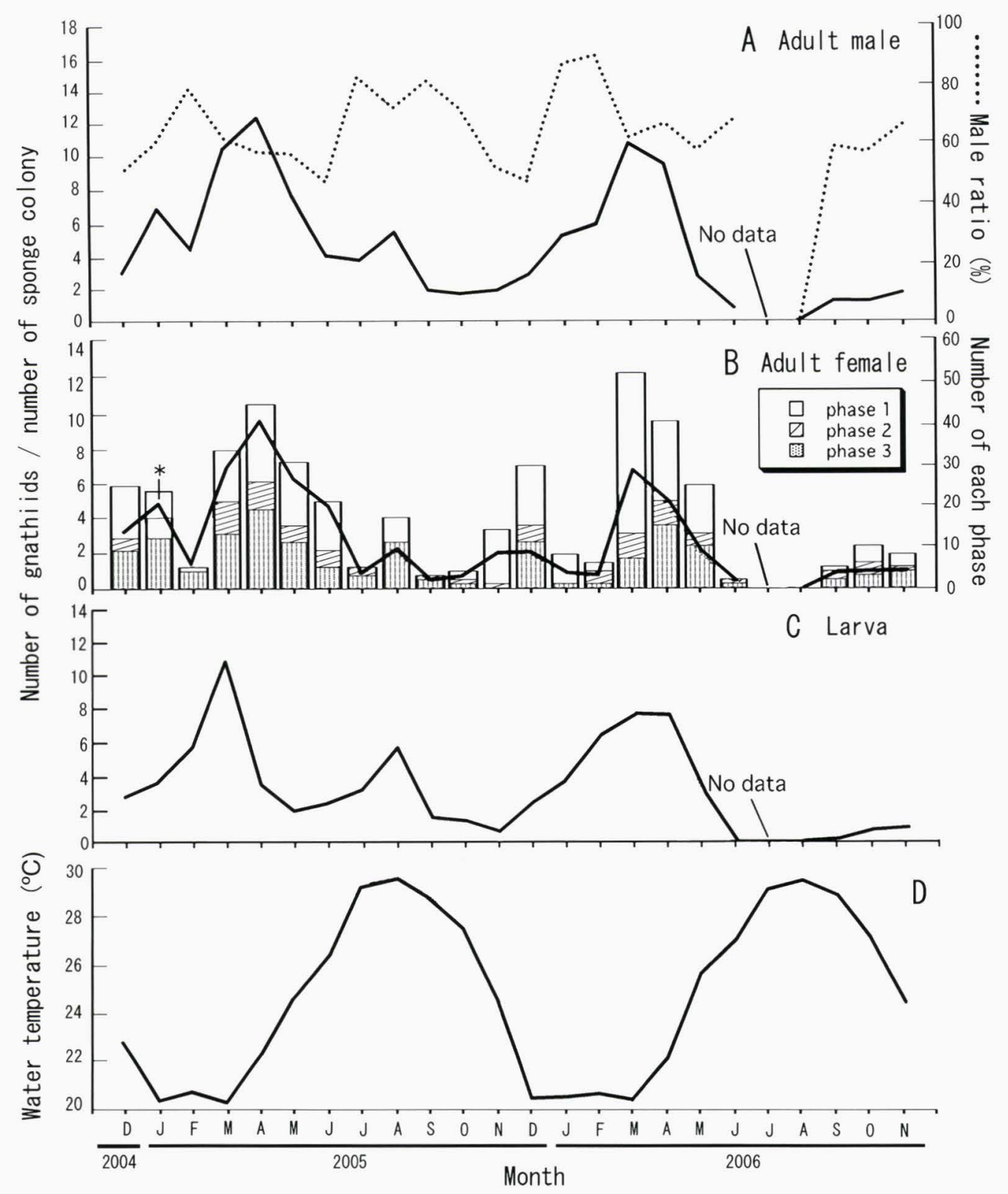

Fig. 3. Seasonal changes of the densities of adult males (A), adult females (B), and larvae (C) of Elaphognathia aff. cornigera and water temperature (D). A and B also showed seasonal changes in the male ratio (no. of males / no. of both adults $\times 100$ ) of adult gnathiids, and the number of adult females at each reproductive phase, respectively. The asterisk in January 2005 indicates broken specimens and unknown phases. In July 2006, sponge colonies could not be collected because of stormy weather. 


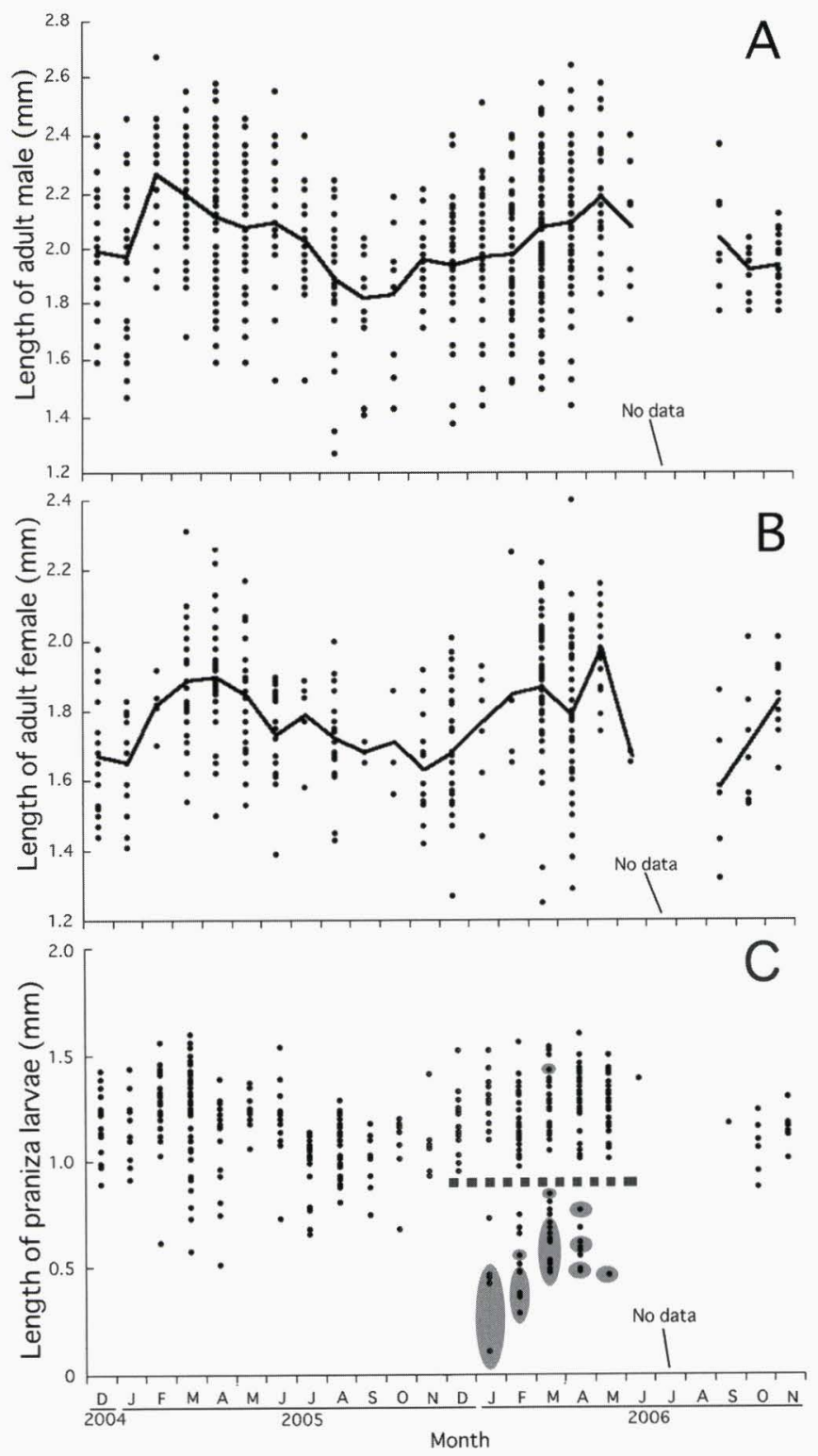

Fig. 4. The size distributions of adult males, adult females, and larvae of Elaphognathia aff. cornigera during each month. Body sizes are defined as the length from the head to the tip of the pleotelson without the mandibles for adult males, from the head to the tip of pereonite 6 for adult females, and from the head without mandibles to pereonite 6 for larvae. Lines indicate the average sizes for adult males and adult females. Average lengths are not shown for larvae because the samples likely included multiple developmental stages. The broken line indicates a gap in the larval sizes and gray ellipses indicate pre-feeding larvae. In June 2006, sponge colonies could not be collected because of stormy weather. In July 2006, sponge colonies could be collected but no gnathiids were found. 
Halichondria okadai although larvae showed different vertical distributions from those of adults (Tanaka \& Aoki, 1999). Thus, this gnathiid species was thought to utilize the sponge throughout its life cycle (Tanaka \& Aoki, 1998).

In the present study, most larval Elaphognathia aff. cornigera were of similar size to adults, suggesting that most of the larvae in Haliclona sp. were premature individuals. In contrast, small larvae were relatively scarce in our surveys. Thus, we hypothesize that Haliclona sp. is mainly used by Elaphognathia aff. cornigera during metamorphosis and reproduction, and young larvae use other habitats such as rock crevice and muddy substrata. In the present study, however, we did not collected young larvae from the habitats other than Haliclona sp. because we could not make specific identification of the young larvae that might include other gnathiid species. This type of habitat utilization may be similar to the Antarctic $C$. calva, and different from $E$. cornigera, a congener of the present gnathiid, which utilizes demosponges throughout its life cycle. Note that Haliclona sp. colonies were not the only habitat available for gnathiid reproduction because adults were occasionally collected from other sponge species and rock crevices.

During most months, Elaphognathia aff. cornigera tended to aggregate in particular sponge colonies. Factors influencing benthic distribution patterns of gnathiids are not fully understood but chemical communication among individuals has been reported. Upton (1987b) observed that all larval stages of Paragnathia formica were attracted to mud containing adult males. The presence of benthic conspecific individuals was hypothesized to indicate suitable benthic settlement sites, where post-settlement mortality due to anoxic mud was low for postfeeding larvae, which would have previously been on host fishes (Upton 1987b). Although further investigation is needed to confirm this conclusion, the detection of chemicals released from congeners might cause an aggregated distribution of Elaphognathia aff. cornigera and improve settlement success and encounter rates.

\section{Seasonal fluctuations of Elaphognathia aff. cornigera}

Differences in occurrence patterns between sexes by season have been recorded for a few temperate gnathiid species. In the Afro-European species $P$. formica, adult females are absent and only adult males and larvae remain during colder months (Upton, 1987a). The absence of adult females in the winter has also been recorded for the population of E. cornigera in the Izu Peninsula (southern Japan) (Tanaka \& Aoki, 2000; Tanaka, 2003). In these gnathiid species, larval growth is thought to halt during cold conditions and development from larvae to adults stops from autumn onward. Semelparous females die after this developmental pause, and only larvae and adult males with greater longevity than females survive during colder months (Upton, 1987a; Tanaka \& Aoki, 2000; Tanaka, 2003).

In contrast to females of $P$. formica and $E$. cornigera, which have limited reproductive periods (Upton, 1987a; Tanaka \& Aoki, 2000), adult females of Elaphognathia aff. cornigera were collected almost year-round in the present study. Furthermore, three reproductive phases were observed for adult females in most months, while sex ratios showed some fluctuations. This suggests that the present species continued to reproduce during the winter, as well as during the warmer months. The larval growth of $P$. formica was suggested to cease below $4{ }^{\circ} \mathrm{C}$ in the laboratory (Stoll, 1962) and almost no adult females of $E$. cornigera emerged when water temperatures were below $18{ }^{\circ} \mathrm{C}$ (Tanaka \& Aoki, 2000; Tanaka, 2003). However, water temperatures in our subtropical sampling area were always above 20 ${ }^{\circ} \mathrm{C}$. In the present species, the warm environmental conditions may not prevent larval growth during the winter and likely contributes to the continuous occurrence of adult females throughout the year. 
Seasonal changes in the abundance of Elaphognathia aff. cornigera are also different from those of $P$. formica or $E$. cornigera. In the two temperate species, population density decreases during the winter because no reproduction occurs (Upton, 1987a; Tanaka \& Aoki, 2000). In our study, the maximum density of Elaphognathia aff. cornigera in the sponge Haliclona sp. was reached during the winter or spring, while minimum densities occurred in the fall of 2005 and the summer of 2006. Low overall densities during warmer months do not appear to be attributable to seasonality in reproductive activity because ovigerous females were found throughout the year. Similar drastic changes in population density with continuous reproduction in females have been observed in other organisms in warm waters. In the gammarid Eripisa chilkensis from an estuarine in the southwest coast of India, population density decreased to 0 in February, although breeding occurred almost year-round (Aravind et al., 2007). In an undescribed sponge-dwelling amphipod species, occasionally referred to as Leucothoe "spongicola," in the Indian River Lagoon of east-central Florida, juveniles and subadults were only abundant in May even though ovigerous females were observed throughout the year (Thiel, 2000). Aravind et al. (2007) thought that a decrease in $E$. chilkensis density was associated with environmental conditions such as high salinity and/or high organic matter. Thiel (2000) suggested that the exposure of sponges for long periods during warmer months occurs when water levels are low and L. "spongicola" may change habitats in response to severe water loss.

In the tidal flat where the present investigation was conducted, sudden increases or decreases in salinity, extreme high temperature, and eventual exposure of sponges can occur during warmer months (pers. obs.). Such severe environmental conditions provide possible explanations for the low density of Elaphognathia aff. cornigera during warmer months. Furthermore, from sum- mer to fall, our study site is characterized by stormy weather, including typhoons. When struck by typhoons, sponges inhabited by gnathiids may be washed out from shallow tidal flats. Rapid water movements may also prevent gnathiids from seeking and settling on favorable habitats. More information is needed on the physical factors affecting the abundance of Elaphognathia aff. cornigera. Furthermore, the habitats for young larval stages should be disclosed in future studies.

The present species Elaphognathia aff. cornigera exhibits differences in habitat use and seasonal emergence patterns from the congener E. cornigera. Although the taxonomic status of the present gnathiid requires further study, ecological characteristics suggest that Elaphognathia aff. cornigera is a distinct species. Spatiotemporal distributions of this gnathiid species may be due to as responses to environmental conditions, including physical and biological factors such as the availability of suitable habitats. Further understanding of the ecological plasticity to different environmental conditions exhibited by these animals, as well as intensive taxonomical efforts, are, however, needed to confirm these points.

\section{Acknowledgements}

We thank Dr. Y. Ise, Misaki Marine Biological Station, for sponge identifications and Ms. T. Inoue, University of the Ryukyus, for assistance during field sampling. We also thank Dr. A. S. Grutter, University of Queensland and an anonymous reviewer for the critical reading and useful comments. This study was supported in part by the Fujiwara Natural History Foundation to YO and the $21^{\text {st }}$ Century COE program of the University of the Ryukyus to EH.

\section{Literature Cited}

Aravind, N. P., Sheeba P., Nair, K. C. C., \& Achuthankutty, C. T., 2007. Life history and population dynamics of an estuarine amphipod, Eriopisa chilkensis Chilton 
(Gammaridae). Estuarine Coastal and Shelf Science, 74: 87-95.

Arnal, C., \& Côté, I. M., 2000. Diet of broadstripe cleaning gobies on a Barbadian reef. Journal of Fish Biology, 57: 1075-1082.

Cheney, K. L., \& Côté, I. M., 2003. The ultimate effect pf being cleaned: does ectoparasite removal have reproductive consequences for damselfish clients? Behavioral Ecology, 14: 892-896.

Grutter, A. S., 1995. The relationship between cleaning rates and ectoparasite loads in coral reef fishes. Marine Ecology Progress Series, 118: 51-58.

$\longrightarrow, 1999$ a. Cleaner fish really do clean. Nature, 398: 672-673.

, 1999b. Infestation dynamics of gnathiid isopod juveniles parasitic on the coral-reef fish Hemigymnus melapterus (Labridae). Marine Biology, 135: 545-552.

,2003. Feeding ecology of the fish ectoparasite, Gnathia sp. (Crustacea: Isopoda), from the Great Barrier Reef, Australia and its implications for fish cleaning behaviour. Marine Ecology Progress Series, 259: 295-302.

—, Morgan, J. A. T., \& Adlard, R. D., 2000. Characterising parasitie gnathiid isopod species and matching life stages with ribosomal DNA ITS2 sequences. Marine Biology, 136: 201-205.

Hesse, E., 1864. Mémoire sur les pranizes et les ancés et sur les moyens curieux ál'aide desquels certains crustacés parasites assurent la conservation de leur espèce. Mémoires des Savants Etrangers Présentés à l'Académie des Sciences, Paris, 18: 231-302.

Jones, C. M., Nagel, L., Hughes, G. L., Gribb, T. H., \& Grutter, A. S., 2007. Host specificity of two species of Gnathia (Isopoda) determined by DNA sequencing blood meals. International Journal for Parasitology, 37: 927-935.

Klitgaard, A. B., 1991. Gnathia abyssorum (G. O. Sars, 1872) associated with sponges. Sarsia, 76: 33-39.

$\longrightarrow$, 1997. The distribution and habitats in the North Atlantic of gnathiid species (Crustacea, Isopoda) and their reproductive biology in Denmark Strait and north of Iceland. Meddelelser om Grønland, Bioscience, 47: 5-32.

McKiernan, J. P., Grutter, A. S., \& Davis, A. J., 2005. Reproductive and feeding ecology of parasitic gnathiid isopods of epaulette sharks (Hemiscyllium ocellatum) with consideration of their role in the transmission of a haemogregarine. International Journal for Parasitology, 35: 19-27.

Monod, T., 1926. Les Gnathiidae. Mémories de la Société des Sciences Naturelles du Maroc, 13: 1-668.

Morisita, M. (1959) Measuring of the dispersion of individuals and analysis of the distributional patterns. Memories of Faculty of Science, Kyushu University, Series E (Biology), 2: 215-235.

Mouchet, S., 1928. Note sur le cycle évolutif des Gnathiidae. Bulletin de la Société Zoologique de France, 53: 392-400.

Nunomura, N., 1992. Marine Isopoda from Amakusa, Kyushu (II). Publications from the Amakusa Marine Biological Laboratory, Kyushu University, 11: 59-71.

Sikkel, P. C., Scaumburg C. S., \& Mathenia, J. K., 2006. Diel infection dynamics of gnathiid isopod larvae parasitic on Caribbean reef fish. Coral Reefs, 25: 683-689.

Stoll, C., 1962. Cycle evolution of Paragnathia formica (Hesse) (Isopoda-Gnathiidae): Cycle evolutif de Paragnathia formica (Hesse) (Isopode-Gnathiidae). Cahiers de Biologie Marine, 3: 401-416.

Tanaka, K., 2003. Population dynamics of the sponge dwelling gnathiid isopod Elaphognathia cornigera. Journal of the Marine Biological Association of the United Kingdom, 82: 79-84.

$\longrightarrow, 2007$. Life history of gnathiid isopods-current knowledge and future directions. Plankton \& Benthos Research, 2: 1-11.

,$- \&$ Aoki, M., 1998. Crustacean infauna of the demosponge Halichondria okadai (Kubota) with reference to the life cycle of Gnathia sp. (Isopoda: Gnathiidea). In Y. Watanabe \& N. N. Fusetani (eds.), Sponge Sciences: Multidisciplinary Perspectives, Springer-Verlag, Tokyo, 259-267.

,$- \&-, 1999$. Spatial distribution patterns of the sponge-dwelling gnathiid isopod Elaphognathia cornigera (Nunomura) on an intertidal rocky shore of the Izu Peninsula, southern Japan. Crustacean Research, 28: 160-167.

,$- \&-, 2000$. Seasonal traits of reproduction in a gnathiid isopod Elaphognathia cornigera (Nunomura, 1992). Zoological Science, 17: 467-475.

— \& Nishi, E., 2008. Habitat use by the gnathiid isopod Elaphognathia discolor living in terebellid polychaete tubes. Journal of the Marine Biological Association of the United Kingdom, 88: 57-63. 
Thiel, M., 2000. Population and reproductive biology of two sibling amphipod species from ascidians and sponges. Marine Biology, 137: 661-674.

Upton, N. P. D., 1987a. Asynchronous male and female life cycles in the sexually dimorphic, harem-forming isopod Paragnathia formica (Crustacea: Isopoda). Journal of Zoology, 212: 677-690.

, 1987b. Gregarious larval settlement within a restricted intertidal zone and sex differences in subsequent mortality in the polygynous saltmarsh isopod Paragnathia formica (Crustacea: Isopoda). Journal of the Marine
Biological Association of the United Kingdom, 67: 663-678.

Wägele, J. W., 1988. Aspects of the life-cycle of the Antarctic fish parasite Gnathia calva Vanhöffen (Crustacea: Isopoda). Polar Biology, 8: 287-291.

Addresses: ( $\mathrm{YO}$ and $\mathrm{EH})$ University of the Ryukyus, Senbaru, Nishihara, Okinawa, 903-0213, Japan; (KT) Central Research Institute of Electric Power Industry, Gasonji, Chiba 270-1194, Japan

E-mail: (YO) yuzomushi@yahoo.co.jp 